Szegedi Tudományegyetem, Fogorvostudományi Kar, Fogpótlástani Tanszék, Szeged*

Pécsi Tudományegyetem Fogorvostudományi Szak, Fogpótlástani Tanszék, Pécs**

Szegedi Tudományegyetem, Fogorvostudományi Kar, Konzerváló és Esztétikai Fogászati Tanszék, Szeged**

Szegedi Tudományegyetem, Fogorvostudományi Kar, Orális Biológiai és Kísérletes Fogászati Tanszék, Szeged ${ }^{* \star \star \star}$

\title{
Részleges kivehető fémlemezes pótlások tervezése a gyakorlatban I.
}

\author{
DR. RADNAI MÁRTA*, DR. MARADA GYULA**, DR. T. SZABÓ VERONIKA**, TARJÁNYI TAMÁS****, DR. BARÁTH ZOLTÁN*
}

\begin{abstract}
Részleges kivehető fémlemezes műfogsorok a mindennapi betegellátásban gyakran készülnek még napjainkban is. Ezek tervezését a fogorvosnak a biológiai, statikai, anyagtani, esztétikai szempontok szerint és a betegek igényeit, elvárásait figyelembe véve kell megvalósítania. Kérdőíves felmérést végeztünk fogtechnikusok körében annak kiderítésére, mennyire valósul meg ez a gyakorlatban. A 64 fogtechnikus válasza szerint a fogorvosoknak alig több mint fele (52\%) küld pontos tervet az öntött kapocs elhorgonyzású részleges kivehető fémlemezes műfogsorok készítéséhez a laborba, kapcsok fajtájára nézve 47\%-ban érkeznek információk, a nagy összekötők formájára nézve 28\%-ban kap útmutatást a labor. Az utasítások 6\%-ban rajzosan, 48\%-ban írásban, vagy írásban és rajzzal (31\%) érkeznek. Az esztétikai probléma esetében felmerülő felelősség a technikust és a fogorvost is terheli a vélemények szerint, akárki végzi a tervezést. A technikusok 86\%-a szükségesnek tartotta, hogy a részleges kivehető fémlemezes fogpótlások tervezésében a fogorvos is részt vegyen. Szakirodalmi megállapítások hasonló adatokat mutattak, ennek ellenére helytelen az a gyakorlat, hogy a fogorvosok meglehetősen sokszor a fogtechnikai laborra bízzák a fogsorok megtervezését.
\end{abstract}

Kulcsszavak: fogorvos, fogtechnikus, részleges kivehető fogsor, tervezés

\section{Bevezetés}

Magyarországon [6] egy nagy létszámú populációban a 45-64 éves korosztályban a vizsgált személyek $26,1 \%$ nak átlagosan kevesebb mint 15 foga megtartott. Az idősebb korosztályban ez már majdnem $40 \%$-ra volt jellemző 2004 évi adatok szerint. llyen mértékü foghiányt mindenképp pótolni kell, amire többféle lehetőség nyílik. A foghiányok, a meglévő fogak és egyéb fontos befolyásoló tényezők alapján lehet dönteni rögzített vagy kivehető fogpótlások készítése között. Tekintettel arra, hogy az egyre inkább elterjedő implantációs pótlásokat nem mindenki kéri, vagy különféle okok miatt nincs lehetőség implantátum beültetésére, a mai napig készülnek részleges kivehető müfogsorok a mindennapi gyakorlatban. Ezek tervezése pedig a fogorvos feladata [8], hiszen a fogorvos ismeri a beteget, az ő igényeit és elvárásait, problémáit, szisztémás betegségeit, gyógyszereit, szájhigiénés szokásait, várható együttmúködését, a fogak prognózisát, a fogatlan gerinc és a nyálka hártya állapotát, az antagonista viszonyokat. További fontos tényezők a tervezésben a beteg neme, életkora, fizikuma, esetleges rossz szokásai, mint például a csikorgatás, ami fokozott terhelést jelent a készülő fogpótlásra. A klinikai vizsgálat során a fogorvos felméri a fogak kariológiai, endodonciai és parodontológiai állapotát. $A z$ eszközös vizsgálómódszerek (szondázási mélységmérés, vérzés szondázásra, mobilitás felmérése) mel- lett csak a fogorvos rendelkezésére állnak a különböző röntgenfelvételi technikák, amelyekkel megítélhető a fogak parodontológiai állapota, a klinikai korona-gyökér arány. Ezek a tényezők segítenek a tervezésben, a pillérfogak, a kapocsfajták, a fémlemezes múfogsor egyéb alkotóelemeinek megtervezésében. A fogtechnikai laborban a fogsorok tervezéséhez használt eszközök, így egy paralelométer vagy egy artikulátor a rendelöben is könynyen beszerezhető. Az információ átadása és a pontos utasítások nagyon fontosak a készítendő fogpótlás minősége szempontjából, hiszen ha nem a követelményeknek megfelelő fogsorok készülnek, azok rövid és/vagy hosszú távon károsíthatják a teherviselő vagy a fogsorral érintkező szöveteket. Kifogástalan funkció is csak az adott szituációban optimálisan megtervezett fogsortól várható. Ellenkező esetben a pillérfogak, a nyálkahártya-csontalapzat túlterhelődhet, a fogsor nem jól illeszkedik, nem stabil, a rágófelszíni támasztékok zavarhatják az okklúziót, esetleg a beteg képtelen rágni vagy beszélni a fogsorral. Átadás után a páciens többször fog jelentkezni fájdalom vagy egyéb probléma miatt korrekciót kérve.

Jogi szempontból is a fogorvos felelős a tervezésért és a kivitelezésért is, mivel ő áll kapcsolatban a beteggel, ő kapja a „megbízást” a fogpótlás elkészítésére, majd ő adja át a fogsort, a fogorvos fogja a szükséges korrekciókat elvégezni és nála jelentkezik a beteg, ha nem elégedett, mert nem tudja használni a fogsort vagy esztétikai kifogásai vannak [9]. 
Etikai szempontból is a fogorvos felelőssége a beteg állapotának körültekintő felmérése, vizsgálata, a diagnózisok felállítása, és ezek és a tervezést befolyásoló egyéb tényezők figyelembevételével a fogsor megtervezése [3]. Az orvosi etika alapelvei lefektetik többek között, hogy „Mindig jót tenni a betegeknek és nem ártani" [1]. Ez egyértelmúen magában foglalja, hogy a részlegesen foghiányos beteget a fogorvosnak legjobb tudása szerint kell ellátni és ezt a felelősséget nem háríthatja a fogtechnikusra, bármilyen jól dolgozik is.

Mindezek ellenére a mindennapi gyakorlat azt mutatja, hogy a fogorvosok nem mindig tervezik meg a részleges fémlemezes múfogsorokat. A mai hazai gyakorlat kiderítésére egy kérdőíves felmérést végeztünk fogtechnikusok és fogorvosok körében. A témával foglalkozó első közleményünk fő célja fogtechnikusok válaszainak elemzése arra vonatkozóan, hogy az öntött kapoccsal elhorgonyzott részleges kivehető fémlemezes fogsorok (továbbiakban: részleges kivehető fémlemezes müfogsor, részleges kivehető protézis) készítéséhez kapnak-e, ha igen, milyen részletes útmutatót a fogorvosoktól. További célja a közleménynek, hogy felhívjuk az azt olvasó fogorvosok figyelmét arra, hogy a részleges fémlemezes múfogsorok készítése során fontos feladatuk a pótlás megtervezése.

\section{Anyag és módszer}

Kérdőíves módszerrel adatokat gyűjtöttünk fogtechnikusoktól arra nézve, milyen információkat, adatokat kapnak a részleges fémlemezes fogsorokat megrendelő fogorvosoktól. A kérdőív összeállításában gyakorló fogtechnikusok véleményét is figyelembe vettük. Első próbálkozásként interneten elérhető címekre levélben (50 db) küldtük el a kérdőívet a kitöltésre vonatkozó tájékoztatóval, erre azonban csak három válasz érkezett. Ezután a Földvári Imre Nemzetközi kongresszus résztvevőit a felmérés céljáról való részletes szóbeli tájékoztatás után kértük a kérdőív kitöltésére Szegeden, 2019 novemberében. A kérdéseket előzetes tájékoztatás után önkéntesen és név nélkül összesen 64 fogtechnikus válaszolta meg.

A kérdőív a következő fő témakörökre fókuszált: Küldenek-e a fogorvosok elegendő információt a fémlemez készítéséhez a laborba, ha igen, milyen részletes és pontos az információ. Vonatkozik-e a megrendelés a kapcsok fajtájára, a helyére, a nagy összekötők formájára? Milyen módon kapja a technikus az utasításokat? Írásban, rajzzal vagy mindkettőt kap? A hiba esetén felmerülő felelősségröl való állásfoglalást a következő kérdésekre adott válaszokban kaptuk meg: $\mathrm{Ha}$ a fogtechnikus tervez és a beteg esztétikai okok miatt nem fogadja el a kész munkát, kit terhel a felelősség az esetleges újrakészítésért? Ha a fogorvos tervez és a beteg esztétikai okok miatt nem fogadja el a kész munkát, kit terhel a felelősség az esetleges újrakészítésért?
Ha a fogtechnikus tervez, és a rágófelszíni támaszték miatt nem tud a beteg teljesen összeharapni, akkor kit terhel a felelősség? PI. nem kapott a labor antagonista lenyomatot vagy mintát a munka megrendelésekor. Néhány kérdés arra vonatkozott, hogy a technikusok igénylik-e a közös megbeszélést a tervezés kapcsán a fogorvosokkal. Csak azokat a válaszokat dolgoztuk fel, amelyekre a technikusok nagy része válaszolt, mert pl. a gyakoriságra vonatkozó kérdésekre nagyon kevés választ kaptunk.

\section{Eredmények}

A választ adók átlagosan 14,4 éve készítenek részleges kivehető fémlemezes müfogsorokat, $72 \%$-uk dolgozik megyeszékhelyen vagy nagyobb városban. A fogorvosok $42 \%$-a (26 nem válasz a kérdésre) nem küld pontos tervet a laborba. A kapocstartó fogakat 38\%ban jelölik meg a fogorvosok, a kapcsok fajtájára nézve 47\%-ban érkeznek információk, a nagy összekötők formájára nézve csak $28 \%$-ban kap útmutatást a labor (1. táblázat). Az utasítások kisebb részben rajzosan (6\%), nagyobb részt írásban (48\%) érkeznek, de vannak kollégák, akik írásban és rajzzal is terveznek (31\%) azok közül, akik egyáltalán küldenek utasítást a technikusnak. A válaszok szerint a fogorvosoknak kevesebb mint harmada (28\%) rajzolja be az egyéni kanál határait, ha azt rendel a definitív lenyomatvételhez. A felelősség kérdésére adott válaszok szerint a felelősség megoszlik a fogorvos és a fogtechnikus között. Ha a fogtechnikus tervez és a beteg esztétikai okok miatt nem fogadja el a kész munkát, kérdésre a technikusok $36 \%$ szerint a fogorvost terheli a felelősség, $5 \%$ szerint a technikust, és $59 \%$ szerint mindkettőjüket. Ha a fogorvos tervez és a beteg esztétikai okok miatt nem fogadja el a kész munkát, akkor a vélemények azt mutatták, hogy a technikusok nagy része szerint a fogorvos a felelős $(61 \%)$, de vannak akik (36\%) itt is közös felelősséget vélelmeznek. Csak egy technikai problémára tettünk fel kérdést, nevezetesen, ha a fogtechnikus tervez, és a rágófelszíni támaszték miatt nem tud a beteg teljesen összeharapni, akkor kit terhel a felelősség? A választ adók $61 \%$-a okolta a fogorvost, $16 \%$-a a technikust, és $23 \%$ közösen vállalná a hibát (2. táblázat). A fogtechnikusok nagy része (88\%) egyetértett abban, hogy artikulátorba gipszelt minták szükségesek a pontos tervezéshez.

A technikusok $86 \%$-a tartotta szükségesnek, hogy a részleges kivehető fémlemezes müfogsorok tervezésében a fogorvos is részt vegyen. Ehhez 78\%-uk tartotta szükségesnek a közös elméleti felkészítést, valamint (95\%) a közös megbeszélést részleges kivehető fémlemezes müfogsor készítése előtt (3. táblázat). Megoszlottak a vélemények abban a kérdésben, hogy megvalósítható-e minden esetben a rendelői tervezés. A technikusok $47 \%$-a szerint nem, $44 \%$ szerint többnyire, és csak $8 \%$ tartotta megvalósíthatónak. 
A fogorvosok által küldött utasítások gyakorisága

\begin{tabular}{|c|c|c|c|c|}
\hline \multirow{2}{*}{ Kérdések } & \multicolumn{2}{|c|}{ Igen } & \multicolumn{2}{|c|}{ Nem } \\
\hline & $\mathbf{n}$ & $\%$ & $\mathbf{n}$ & $\%$ \\
\hline Ha a fogorvos egyéni kanalat rendel a lenyomathoz, berajzolja-e a határokat? & 18 & 28 & 46 & 72 \\
\hline A fogorvos általi tervezésben kap-e utasítást a kapcsok fajtájára? & 30 & 47 & 34 & 53 \\
\hline A fogorvos általi tervezésben kap-e utasítást a kapcsok helyére? (1 fő nem válaszolt) & 24 & 38 & 39 & 62 \\
\hline A fogorvos általi tervezésben kap-e utasítást a nagy összekötők formájára? & 18 & 28 & 46 & 72 \\
\hline
\end{tabular}

2. táblázat

Kérdések és válaszok a felelösség témájában

\begin{tabular}{|c|c|c|c|c|c|c|}
\hline \multirow{2}{*}{ Kérdések } & \multicolumn{2}{|c|}{ Fogorvost } & \multicolumn{2}{|c|}{ Fogtechnikust } & \multicolumn{2}{|c|}{ Mindkettőt } \\
\hline & $n$ & $\%$ & $\mathbf{n}$ & $\%$ & $\mathbf{n}$ & $\%$ \\
\hline $\begin{array}{l}\text { Ha a fogtechnikus tervez és a beteg esztétikai okok miatt nem fogadja el a } \\
\text { kész munkát, kit terhel a felelősség az újrakészítésért? ( } 3 \text { fő nem válaszolt) }\end{array}$ & 22 & 36 & 3 & 5 & 36 & 59 \\
\hline $\begin{array}{l}\text { Ha a fogorvos tervez és a beteg esztétikai okok miatt nem fogadja el a kész } \\
\text { munkát, kit terhel a felelősség az újrakészítésért? }\end{array}$ & 39 & 61 & 2 & 3 & 23 & 36 \\
\hline $\begin{array}{l}\text { Ha a fogtechnikus tervez és a rágófelszíni támaszték miatt nem tud a beteg } \\
\text { teljesen összeharapni, akkor kit terhel a felelősség? PI. nem kapott a labor } \\
\text { antagonista mintát vagy lenyomatot, harapás regisztrátummal a munka } \\
\text { megrendelésekor }\end{array}$ & 39 & 61 & 10 & 16 & 15 & 23 \\
\hline
\end{tabular}

Fogtechnikusok véleménye a fogorvosok részvételéról a tervezésben

\begin{tabular}{|c|c|c|c|c|}
\hline \multirow{2}{*}{ Kérdések } & \multicolumn{2}{|c|}{ Igen } & \multicolumn{2}{|c|}{ Nem } \\
\hline & $\mathbf{n}$ & $\%$ & $\mathbf{n}$ & $\%$ \\
\hline $\begin{array}{l}\text { Szükségesnek tartja-e, hogy a részleges kivehető fémlemezes fogpótlások tervezésében } \\
\text { a fogorvos is részt vegyen? }\end{array}$ & 55 & 86 & 9 & 14 \\
\hline Véleménye szerint, ha a fogorvos részt vesz a tervezésben, várható-e benne minőségi javulás? & 51 & 80 & 13 & 20 \\
\hline $\begin{array}{l}\text { Ha a fogorvos úgy dönt, hogy részt kíván venni a tervezésben, szükségesnek tartja-e } \\
\text { a közös elméleti felkészítést? }\end{array}$ & 50 & 78 & 14 & 22 \\
\hline $\begin{array}{l}\text { Szükségesnek tart-e közös megbeszélést a fogorvos és fogtechnikus között } \\
\text { a fémlemez készítése előtt? ( } 2 \text { fő nem válaszolt.) }\end{array}$ & 59 & 95 & 3 & 5 \\
\hline
\end{tabular}

\section{Megbeszélés}

A felmérésben sajnos kevés fogtechnikus vett részt, így az nem mondható reprezentatívnak az ország egészére nézve, azonban az eredmények elgondolkodtatók. Az elemzés azt mutatta, hogy a technikusok nagy részt a betegre vonatkozó klinikai információk nélkül végzik a tervezést, hiszen a fogorvosok majdnem fele (42\%) nem készít, és nem küld pontos tervet a laborba, holott ez a feladata és kötelessége lenne. A válaszok alapján, ha kapnak is információt a fogtechnikusok, az meglehetősen hiányos a pillérfogak és a kapocsfajták kiválasztása, valamint a nagy összekötő formája tekintetében. Több részletre nem kérdeztünk rá, de feltehetően egyéb tervezési szempontra sem érkezik pontos utasítás.

A hazai felméréshez hasonló eredményeket mutattak külföldön végzett vizsgálatok is. Egy 2009-ben Angliában, Írországban és Walesben végzett felmérés szerint 144 kérdőív feldolgozása alapján a fogorvosok 54\%-a kérte meg a technikust a fogsor megtervezésére [4] és csak $6 \%$ (9 fogorvos) küldött olyan mintát a laborba, amin elózetesen paralelométerben felmérte a behelyezési irányt, kapocstartásra alkalmas alámenős felszíneket. Egy másik felmérésben 110 kérdőív válaszait elemezték [7] és hasonló helyzet mutatkozott, miszerint a fogorvosok $43,6 \%$ teljesen a labor munkájára támaszkodott a tervezésben. Azok közül, akik valamilyen utasítást küldtek a laborba, csak $18,2 \%$ adott egyértelmü, világos, pontos leírást, $31,8 \%$ adott valamilyen iránymutatást, de több részlet a fogtechnikusra volt bízva. Jelen felmérésben a technikusok válaszai szerint csak 2\%-ban kaptak pontos utasítást, 39\%-ban valamilyen iránymutatást, és 55\%-ban a legtöbb részlet a fogtechnikusra van bízva. Ez azt mutatja, hogy a fogorvosok nagyfokú bizonytalanságot mutatnak a részleges fogsorok tervezésének témájában, amin pedig javítani kellene, hiszen ez a nem megfelelő minőségú betegellátáshoz vezethet. 
Az utasítások minőségét értékelte egy kínai kutatócsoport [5], jónak értékelték az utasítások $24 \%$-át, közepesnek 45\%-át, gyengének 17\%-át és kifejezetten hiányosnak, vagy nem volt utasítás egyáltalán $14 \%$-ban. Ennek kissé ellentmond, hogy a kapcsok helyére és típusára nézve $90 \%$-ban érkezett utasítás (47\% jelen felmérésben), a nagy összekötők formájára nézve pedig 88\%-ban (nálunk 28\%). Rosszabb eredményt kapott egy másik, 2018-ban közölt felmérés [2], amiben nagyszámú kérdőívet dolgoztak fel. A fogorvosoknak csak 37,5\%-a adott instrukciókat a labornak, amelyekben leggyakrabban $(67,8 \%)$ a kapocs típusát jelölték meg. A protetikusok $57,5 \%$-a, az általános ellátásban dolgozók 33,4\%-a nyújtott részletes információt a tervezéshez.

Optimális és követendő eljárás a tervezésben, ha a fogorvos a beteg vizsgálata és a tanulmányi minták artikulátorba gipszelése után kijelöli a kapocstartó fogakat, meghatározza a retenciós és vezetőkarok, a rágófelszíni támasztékok helyét, valamint a kis- és nagy összekötők helyét és formáját [10]. Szükség esetén a mintára készített rajz kiegészíthető egyéb rajzzal, kéréssel vagy utasítással. Az alámenős részek, párhuzamos felszínek megkereséséhez és a fémlemez részeinek berajzolásához szükséges és elengedhetetlen egy egyszerű paralelométer beszerzése a rendelőbe és használatának megtanulása. A pontos mérések, az öntés előtti berajzolás és a viaszmintázat elkészítése a mestermintán a technikus feladata a fogorvossal való egyeztetés után. A fémlemez tervezése minden esetben közös munka végeredménye a fogorvos és fogtechnikus között.

Érdekes, ha a fogtechnikus tervez és a beteg esztétikai okok miatt nem fogadja el a kész munkát, akkor is a válaszolók $\mathrm{kb}$. harmada a fogorvost teszi felelőssé. Feltehetően azért válaszoltak így, mert a fogorvos nem küldött információt a beteg életkorára, esztétikai igényeire, a mosolyvonal magasságára vonatkozóan. Megjelenik azonban a közös felelösségvállalás is, ahogy a mindennapi gyakorlatban is, a technikusok többször is vállalnak újrakészítést vagy korrekciót külön díjazás nélkül is. Gyakori a válaszokban a felelősség fogorvosra való hárítása, ami azt mutatja, hogy a technikusok szerint is fontos szerepet kell vállalni a fogorvosoknak a pótlások tervezésében.

A munka minősége nagyban javulna a technikusok véleménye szerint, ha a fogorvosok és ők közösen beszélnék meg, hogy az adott beteg számára mi lenne az optimális ellátás. Az erre vonatkozó pozitív válaszok nagy aránya azt mutatja, hogy a fogtechnikusok örülnének a nagyobb együttmüködésnek, jobb kommunikációnak a munka során. Ehhez természetesen szükséges a fogorvosok megfelelő elméleti és gyakorlati felkészültsége és gyakorlata a tervezésben. Fontos lenne az egyetemi oktatás bővítése, továbbképző tanfolyamok szervezése és látogatása a részleges foghiányos bete- gek ellátása témakörben és a rendelőben egy egyszerű paralelométer beszerzése és használata. Ezek teljesülése mellett nem lenne olyan (egyébként helytálló) megjegyzés a válaszok között, mint pl. a „fogorvos akkor vegyen részt a tervezésben, ha eleget tanul ehhez". Úgy látszik, a technikusok nem is bíznak abban, hogy a fogorvos jól meg tudja tervezni a kapoccsal elhorgonyzott fémlemezes múfogsorokat $(47 \%$ nem tartotta lehetségesnek a rendelői tervezést minden esetben). A fogorvosok jó elméleti és gyakorlati felkészültsége, kiegészítve a fogtechnikusok ismereteivel és munkájával, elengedhetetlen a betegek magas szintű ellátásához a részleges foghiányok esetében is.

\section{Köszönetnyilvánítás}

A szerzők köszönetüket fejezik ki Hódi László és Busa Zoltán fogtechnikus mestereknek a kérdések összeállításában adott segítségért, valamint a Földvári Imre konferencia szervezőjének, Simon Emil fogtechnikus mesternek, a kérdőívek kitöltése megszervezésében nyújtott támogatásáért.

\section{Irodalom}

1. A Magyar Orvosi Kamara Etikai Kódexe https://mok.hu/public/media/source/etikaiKodex/ EtikaiKodex_2018_11_24.pdf (2020.06.21.)

2. CebenI NÖ: Factors Associated With Insufficient Removable Partial Denture Design Instructions. Dent Med Prob/ 2018; 55 (2): 173-177. https://doi.org/10.17219/dmp/89646

3. 1997. évi CLIV. törvény az egészségügyröl https://net.jogtar.hu/jogszabaly?docid=99700154.tv (2020.06.21.)

4. KilfeAther GP, LynCH CD, Sloan AJ, Youngson CC: Quality of communication and master impressions for the fabrication of cobalt chromium removable partial dentures in general dental practice in England, Ireland and Wales in 2009. J Oral Rehabil 2010; 37 (4): 300-305. https://doi.org/10.1111/j.1365-2842.2009.02055.x

5. Lei Sul, Xueying WU, Shumong WU, Ping GaO, Rui Li: The Quality of Written Instructions for Dental Prostheses in China. J Prosthodont 2014; 23 (8): 602-609. https://doi.org/10.1111/jopr.12163

6. Madléna M, Hermann $P$, Jáhn M, FeJérdy $P$ : Caries prevalence and tooth loss in Hungarian adult population: results of a national survey. BMC Public Health 2008; 8: 364. https://doi.org/10.1186/1471-2458-8-364

7. WA MAHMOOD, FM SIDEK: Cobalt chromium denture designs in general practice. Annal Dent Univ Malaya 2001; 8: 29-34. https://doi.org/10.22452/adum.vol8no1.6

8. Principles, concepts, and practices in prosthodontics 1994 Academy of Prosthodontics. J Prosthet Dent. 1995; 73 (1): 73-94. https://doi.org/10.1016/S0022-3913(05)80276-8

9. RaDnAI M: A fogmúvek készítésének jogi vonatkozásai. In: Radnal M: Részleges kivehető fogpótlások. Medicina, Budapest, 2012; 209-211.

10. RADNAI M: Öntött kapoccsal elhorgonyzott részleges fémlemezes múfogsor készítése. In: RaDnal M: Részleges kivehető fogpótlások. Medicina, Budapest, 2012; 101-127. 
Radnal M, Marada Gy, T. Szabó V, TarJányit, Baráth Z

\section{Removable partial denture design in the general dental practice I.}

Even today, removable partial dentures are often provided by general dental practitioners. The dentists during denture design should take into consideration all the biological, static, material and aesthetic aspects and also the needs and expectations of patients. A questionnaire survey has been conducted among dental technicians to find out how much this is realized in practice.

According to the response of 64 dental technicians, who voluntarily filled the anonym questionnaire, a little more than the half $(52 \%)$ of the dentists send a precise and detailed denture design to the dental technical laboratory. Technicians received information relating the type of the clasps in $47 \%$ and a guidance on the shape of major connectors in $28 \%$. Six percent of instructions were provided in drawing, $48 \%$ in writing, and $31 \%$. both in writing and drawing. According to the survey in case of problems with the denture, the responsibility was shared between the technician and the dentist, whoever made the planning. $86 \%$ of technicians stated that dentists should be fully involved in the design of removable partial dentures.

Data from the literature have shown a similar practice, i.e. that dentists in other countries also mainly entrust partial denture design to the dental laboratory, even though this is an incorrect practice.

Keywords: removable partial denture with metal framework, design, dentist, dental technician 